3-1988

\title{
Murder and Capital-Punishment in the Evolving Context of the Post-Furman Era
}

\author{
Ruth D. Peterson \\ Ohio State University, peterson.5@sociology.osu.edu \\ William C. Bailey \\ Cleveland State University, w.bailey@csuohio.edu
}

Follow this and additional works at: https://engagedscholarship.csuohio.edu/clsoc_crim_facpub

Part of the Criminology Commons

How does access to this work benefit you? Let us know!

Publisher's Statement

(c) 1988 Oxford University Press

\section{Original Citation}

Peterson, R. C., W. C. Bailey. (1988). Murder and Capital Punishment in the Evolving Context of the PostFurman Era. Social Forces, 66(2), 774-807.

\section{Repository Citation}

Peterson, Ruth D. and Bailey, William C., "Murder and Capital-Punishment in the Evolving Context of the PostFurman Era" (1988). Sociology \& Criminology Faculty Publications. 86.

https://engagedscholarship.csuohio.edu/clsoc_crim_facpub/86

This Article is brought to you for free and open access by the Sociology \& Criminology Department at EngagedScholarship@CSU. It has been accepted for inclusion in Sociology \& Criminology Faculty Publications by an authorized administrator of EngagedScholarship@CSU. For more information, please contact library.es@csuohio.edu. 


\title{
POLICE KILLINGS AND CAPITAL PUNISHMENT: THE POST-FURMAN PERIOD
}

\author{
WILLIAM C. BAILEY \\ Cleveland State University \\ RUTH D. PETERSON \\ Ohio State University
}

\begin{abstract}
In view of (1) escalating national attention and political and judicial activity centering on capital punishment during recent years and (2) concomitant changes in police killing rates, this paper investigates the impact of the death penalty on rates of lethal assaults against the police for the post-Furman period, 1973-1984. In keeping with recent investigations of deterrence and general homicides, multiple regression is used as a means of controlling for the influence of possible confounding variables in examining the capital punishment/police killings relationship. Consistent with previous investigations, the present analysis provides no indication that our national return to capital punishment since Furman has had a systematic impact on police homicides. Law enforcement officers are not afforded an added measure of protection in death penalty compared to abolitionist states, nor is there anything but a chance association between the rate of police killings and the level of use of the death sentence for convicted murderers.
\end{abstract}

Americans have long debated the morality and utility of capital punishment. The arguments are varied, but one recurring theme concerns the role of the death penalty in providing police an added measure of protection against lethal violence in the performance of their duties. In general, advocates of capital punishment argue that the death penalty prevents police killings because the threat of possible execution deters persons from carrying lethal weapons and using them against the police when in danger of arrest (Sellin, 1967; van den Haag and Conrad, 1983). Indeed, some insist that the death penalty may be the only sanction that can restrain suspects in danger of being arrested for a crime that could lead to life imprisonment. Van den Haag (van den Haag and Conrad, 1983: 234), for example, notes:

Without the death penalty an offender having committed a crime that leads to imprisonment for life has nothing to lose if he murders the arresting officer. By murdering the officer ...., such criminals increase their chances of escape, without increasing the severity of the punishment they will suffer if caught. 1

1. Van den Haag makes these comments in the context of a debate concerning the 
Accordingly, for van den Haag the threat of death is necessary to reduce the likelihood that police officers will be killed while performing their duties.

Opponents of capital punishment acknowledge that law enforcement is hazardous work and that police safety is of vital concern to the state. Opponents deny, however, that the sanction of death provides the extra measure of protection for police that procapital punishment advocates claim. Rather, they point out that the killing of police officers is not likely to be deterrable due to either the commitment of suspects to carrying out their original criminal mission or because the determinants of police homicides are highly situational and spontaneous. Under circumstances of high commitment to deviance and in highly emotional situations, consideration of sanctions and deterrence is unlikely. (See, for example, Conrad's response to van den Haag in van den Haag and Conrad, 1983.)

Whatever the merits of abolitionist arguments, most state legislatures would seem either to have accepted the procapital punishment view or to regard the provision of the death penalty for the killing of police officers as an important symbol. Presently, 37 of the 50 states provide for the death penalty in the case of murder, with many retentionist jurisdictions making the killing of a law enforcement officer while in the line of duty a specific capital offense. Among retentionist states without separate statutes, all but one (Connecticut) make the killing of a law enforcement officer a specific aggravating factor in deciding whether the death penalty should be imposed upon an offender.

Despite the extensive discussion that the death penalty has provoked, and despite the apparent faith that legislators have in capital punishment (as a threat or as a symbol) vis-à-vis police killings, there is relatively little empirical support for the claims of either opponents or proponents. Instead, the role of the death penalty in police killings has been largely a neglected area of deterrence research. The present analysis is an attempt to help rectify this situation.

\section{THE PRESENT INVESTIGATION}

To contribute to a better understanding of the relationship between capital punishment and lethal violence against police officers, this research examines a very recent period (1973-1984) in capital punishment history. This period has witnessed an unprecedented amount of public attention and legislative and judicial activity centering on the death penalty. The thrust has been towards a reaffirmation of the death penalty as a criminal sanction for first degree murder, including the killing of a police officer. Changes in activities

pros and cons of the death penalty. Van den Haag argues in favor of capital punishment while Conrad argues against it. The debate is published as a series of essays in van den Haag and Conrad (1983). 
concerning capital punishment have been accompanied by changes in the frequency of police killings. As shown in Table 1, police killing rates were highest during the first four years (1973-1976) considered, and have declined almost steadily since 1976, the period following the Gregg v. Georgia ruling which affirmed the legitimacy of guided discretionary capital punishment statutes. The one exception to this pattern was a slight rise in killings in 1979 , followed by a relatively sharp decline in 1980 . Thus, the substantive question is to what extent the leveling off of police homicides and the more abrupt downturn in the last few years are related to what appears to be growing public, political, and judicial reaffirmation of the death penalty as an institution. To that end, the capital punishment/police killings relationship is examined using a multivariate design similar to those employed in recent death penalty and general homicide investigations (Ehrlich, 1975, 1977; Bowers and Pierce, 1975; Bailey, 1980a, 1980b).

Table 1. Number and Rate of Police Killings, 1973-1984

\begin{tabular}{|c|c|c|c|}
\hline \multirow[b]{2}{*}{ Year } & \multirow{2}{*}{$\begin{array}{c}\text { Number of } \\
\text { Police Killings" }\end{array}$} & \multicolumn{2}{|c|}{$\begin{array}{l}\text { Rate of Police Killings } \\
\text { Per } 100,000 \mathrm{FTE}^{\mathrm{b}}\end{array}$} \\
\hline & & Police Officers & Police Employees \\
\hline 1973 & 127 & - & 25.4 \\
\hline 1974 & 128 & - & 23.7 \\
\hline 1975 & 121 & - & 21.9 \\
\hline 1976 & 106 & - & 19.0 \\
\hline 1977 & 91 & 20.2 & 15.9 \\
\hline 1978 & 89 & 19.3 & 15.3 \\
\hline 1979 & 101 & 21.8 & 17.4 \\
\hline 1980 & 97 & 21.0 & 16.4 \\
\hline 1981 & 88 & 19.0 & 14.9 \\
\hline 1982 & 89 & 19.0 & 14.8 \\
\hline 1983 & 73 & 15.4 & 12.0 \\
\hline 1984 & 70 & 14.5 & 11.3 \\
\hline
\end{tabular}

"Includes only police homicides (excludes deaths resulting from accidents received in the line of duty) in the 50 United States. Also excluded are police killings in U.S. territories. 'It is not possible to compute police killing rates based upon FTE police officers for 1973 . 1976 due to the required police employee data not being available for this period.

\section{DEATH PENALTY/POLICE KILLINGS LITERATURE}

While there is an extensive body of literature examining the relationship between capital punishment and general homicide rates for the nation (Ehrlich, 1975; Bowers and Pierce, 1975; Passell and Taylor, 1975; Yunker, 1976), 
states (Passell, 1975; Bailey, 1977, 1980a, 1980b; Ehrlich, 1977; Forst, 1977, 1983; Black and Orsagh, 1978; McFarland, 1983), and cities (Dann, 1935; Savitz, 1958; Phillips, 1980; Bailey, 1984a, 1984b), very limited research attention has been devoted to the question, "Does the death penalty provide an added measure of protection for the police in the performance of their duties?" Several analyses by Sellin $(1967,1980)$, and one each by Cardarelli (1968) and Bailey (1982) constitute the empirical research on this specific deterrence question.

In an early study, Sellin (1967) compared the rates of police killings in 11 death penalty states and 6 neighboring abolitionist jurisdictions. ${ }^{2}$ The data pertained to the period 1919-1954. He found no support for the deterrence notion that "states which have abolished the death penalty have thereby made the policeman's lot more hazardous" (1967: 147). Instead, average police killing rates per 100,000 population were quite similar in the two types of jurisdictions when total population size was controlled. ${ }^{3}$ As part of the same study, Sellin conducted a separate analysis of police killings in Chicago. He (1967: 152) concluded:

The curve of executions follows generally the trend of the homicide curve. There is nothing to suggest that there is any other relation between the two than that where there are more homicides there are more executions and when there are fewer homicides there are fewer executions.

In a second study, Sellin (1967) replicated his original comparative analysis considering 9 death penalty and 6 neighboring abolitionist states for the period 1961-1963. His later findings confirmed the earlier results. The annual rates of police killings were not significantly different for death penalty than abolitionist jurisdictions.

In a final study of capital punishment and police killings, Sellin (1980) compared the risk of officers being killed (per 1,000 police) in abolitionist versus retentionist jurisdictions for 1975. In this analysis, area of the country (Northeast, North Central, South, West) was controlled. In general, the results were consistent with Sellin's previous findings. In most instances rates were lower in abolitionist than in death penalty states. The finding for the southern region was an exception, however. In the South, the risk of an officer being killed was twice as high in West Virginia, the only abolitionist

2. The 11 death penalty states considered in Sellin's analysis are Connecticut, Illinois, Indiana, Iowa, Massachusetts, Montana, New Hampshire, New York, Ohio, South Dakota, and Vermont. The abolitionist jurisdictions include Maine, Michigan, Minnesota, North Dakota, Rhode Island, and Wisconsin.

3. To avoid possible spurious results due to comparing police killing rates for states that include cities of very different sizes, Sellin analyzed his data for groupings of abolitionist state cities and retentionist state cities of varying sizes: cities with a population of $10,000-30,000 ; 30,000-60,000 ; 60,000-100,000 ; 100,000-350,000$; and 500,000-650,000. 
state, than in the rest of the South. With this exception, three separate analyses by Sellin challenge the view that the death penalty affords police officers greater safety in their occupation.

Additional data on the capital punishment/police killings question comes from an investigation by Cardarelli (1968). As part of a larger analysis of police homicides, he examined the rate of police deaths per 1,000,000 inhabitants and per the number of police employed in abolitionist and neighboring retentionist states. The time period was 1961-1963. Regardless of the population base considered, Cardarelli found very little difference in police killings for the two types of states. He cautioned that due to the small number of police killed in each state, conclusions must be tentative. Nonetheless, he argued that his data lend no credence to the claim that the death penalty affords police a greater level of protection.

The studies by Sellin and Cardarelli are valuable, but they suffer from important limitations that preclude drawing firm conclusions. These limitations are not particular to studies of police killings, but are common to most comparative analyses of the relationship between capital punishment and homicides (of any variety). First, comparisons of neighboring death penalty and abolitionist jurisdictions may not control adequately for various social, economic, demographic, and cultural factors that influence homicide rates (van den Haag, 1969; van den Haag and Conrad, 1983; Ehrlich, 1975; Lehtinen, 1977; Yunker, 1976, 1982a, 1982b). Consequently, such studies may not isolate successfully the possible deterrent effect of the death penalty. Second, although the deterrence doctrine emphasizes the importance of the certainty of sanctions, comparative studies have considered only the statutory provision for the death penalty, not its actual level of use. Both proponents and opponents of capital punishment agree that the death penalty in the law alone cannot provide an effective threat to would-be killers. Thus, adequate tests of deterrence hypotheses must consider both the provision for and the use of capital punishment. In brief, due to (1) possible inadequate controls for likely confounding factors in examining the capital punishment/police killings relationship, and (2) possible inadequate operationalization of the death penalty variables, the works by Sellin $(1967,1980)$ and Cardarelli (1968) may not provide suitable tests of the deterrence hypothesis for police killings.

It appears that only one analysis (Bailey, 1982) of police killings has attempted to address the above limitations. Bailey provided a detailed statelevel multivariate analysis of yearly rates (per 1,000 police employees) of lethal assaults on the police for the period 1961-1971. He considered two capital punishment variables: (1) states' death penalty status (retentionist or abolitionist), and (2) execution rates (that is, certainty) operationalized as the total number of executions for murder each year divided by the total number 
of reported murders during the year. Bailey's analysis also included four control variables: percent poverty, nonwhite population, unemployed, and urban population. Despite these innovations, his findings were very consistent with the earlier comparative analyses. The two death penalty variables were very poor predictors of police killings. In fact, he found no support for the deterrence hypothesis in his initial model of police homicides, nor when various time-lags between executions and police killings were considered. ${ }^{4}$

While Bailey provided a more sophisticated analysis than Sellin or Cardarelli, his findings should not be taken as conclusive evidence that the death penalty is incapable of achieving a marginal deterrent effect on police killings. His findings may in part reflect the social context surrounding capital punishment during the 1960 s and early 1970s. Briefly, Bailey examined a period (1961-1971) during which there was a great deal of skepticism and ambivalence regarding the role and utility of the sanction of death in this country. This ambivalence was reflected in a decline in the use of capital punishment and a questioning of its constitutional legitimacy as a criminal sanction. Since the deterrent impact of a penalty depends upon the message communicated by its provision and use (Gibbs, 1975; Tittle, 1980), the ambivalent views about and declining use of the death penalty during the 1960s may have undermined the extent to which this sanction was perceived as a real and certain punishment. If so, then one would not expect this penalty to have a substantial deterrent effect on the murder of police officers or killings in general and, therefore, Bailey's results would not be surprising.

The social context of capital punishment was quite different in the period (1973-1984) examined here from that in the period examined by Bailey. The post-Furman period has been a highly turbulent and volatile era for capital punishment and one in which the direction has been towards a reassertion of the legitimacy of the sanction. The Furman v. Georgia decision in 1972 amounted to a sweeping constitutional rejection of the death penalty as then applied. This was followed by rapid reinstatement of the penalty by most states and, beginning with Gregg v. Georgia (1976), a reaffirmation of capital punishment by the highest court in the land. 5 These changes sparked an

4. To consider a possible delayed deterrent effect, Bailey examined the relationship between yearly execution rates and average police killing rates for two-year periods (year $t$ + year $t+1) / 2$, and using a three-year average execution rate measure (year $t+$ year $\mathrm{t}-1+$ year $\mathrm{t}-2) / 3$.

5. Briefly, in 1976 the High Court abolished the mandatory death penalty in deciding Woodson v. North Carolina and Roberts (Stanislaus) v. Louisiana but upheld guided discretionary statutes in deciding Gregg v. Georgia. Profitt v. Florida, and Jurek v. Texas. These met the Court's concerns in Furman. The death penalty for rape was struck down in 1977 (Coker v. Georgia), and statutes restricting the scope of certain mitigating circumstances that sentencing courts might hear were struck down by the High Court in 1978 (Lockett v. Ohio). It should be noted that most of these Supreme Court cases did not pertain to police killings directly. An exception was Roberts (Harry) v. Louisiana (1977). 
increase in the use of the death sentence. And, in 1977, there was a resumption of executions after a 10-year moratorium.

In short, since the period (1961-1971) considered in Bailey's (1982) research there has been a general thrust towards reaffirmation and greater use of the death penalty. (See Bowers, 1984, for a more detailed overview of death penalty events both prior to and since Furman.) In such a context, one might expect the existence and application of capital punishment to have a significant negative influence on capital crimes, including the killing of police officers. In fact, there were changes in police killings concomitant with the changes in capital punishment activities over the period under investigation (see Table 1). As indicated, police killings were highest during the earliest years (1973-1976), declining substantially starting in 1977 (the year following Gregg), and continuing through the remaining seven years, with the exception of a slight upturn in 1979. Police killings again dropped rather sharply in 1980 , and have remained relatively low since.

The question considered here is whether the noted death penalty events and concomitant changes in police killings-a special form of capital homicide-since Furman are related systematically or are simply a matter of coincidence. If deterrence is a communication theory (Gibbs, 1975; Tittle, 1980), then perhaps the official reaffirmation of capital punishment by the nation's state and federal appellate courts, its reinstatement by state legislatures throughout most of the country, its increased use in sentencing, and its actual application in highly publicized cases may have signaled to the public in general, including would-be police killers, that capital punishment is once again a reality, and increasingly so. If so, this should be revealed in the pattern of police homicides over the period.

Examination of this special form of capital homicide should provide an important contribution to the general understanding of the role of capital punishment in crime control. First, an underlying assumption of the present analysis is that the role of capital punishment in police killings may vary under different contextual conditions. Examining police killings for the 19731984 period and comparing the findings with Bailey's for 1961-1971 should help specify the types of contexts in which the death penalty may deter police killings. From a policy standpoint, the present analysis will provide data of a "recent vintage" that can be considered in death penalty cases brought before the judiciary. The courts are continuing to hear such cases and have called

In Roberts, the Supreme Court held that a Louisiana statute providing for a mandatory death sentence for the first-degree murder of a police officer violated the Eighth and Fourteenth Amendments because it did not allow for consideration of "particularized mitigating factors in deciding whether the death sentence should be imposed" (Nicolai, Riley, Christansen, Styon, and Creunke, 1980: 34). Thus, in cases dealing with police killings specifically, the High Court continued to outlaw certain practices related to its application, but not the legitimacy per se of the capital sentence. 
for more up-to-date data regarding the deterrent impact of capital punishment (Gregg v. Georgia, 1976; Furman v. Georgia, 1972).

\section{METHODS AND PROCEDURES}

As indicated, this analysis examines the relationship between the rate of police killings and the provision for the death penalty and use of death sentences for the period 1973-1984. The concern is with examining whether shifts in police killings in the 1970s and the early 1980s, including the noted downturn after 1976, can be attributed to (1) the reaffirmation of the death penalty as reflected in judicial and legislative actions and decisions, and/or (2) the growing use of the death sentence since Furman in 1972. If recent policies and events regarding capital punishment have resulted in a deterrent effect, one would expect yearly police killing rates to be significantly higher in abolitionist than in death penalty states and significantly lower in retentionist jurisdictions making greater use of the death sentence for murder. To test these questions, a multivariate design is employed that parallels those found in recent capital punishment and deterrence investigations considering general homicides. Several models of police killing rates are considered using different measures of the certainty of a death sentence. The general model being tested is of the form:

PHR $=f(D P$, EXMOS, DPSEN, BLK, REG, POV, AGE, SEX)

This model represents the hypothesis that the police homicide rate (PHR) is a function of a state's death penalty status-its presence or absence (DP), the number of months during a year when the death penalty was in effect (EXMOS), the ratio (\%) of those sentenced to death to the number of reported yearly homicides (DPSEN), percent black population (BLK), region of the country (REG), percent of families below the poverty line (POV), percent age 15-34 (AGE), and the sex ratio (SEX).

To extend the analysis and to guard against spurious results, a variation of the general model of police killings is examined by including felony rates for violent, property, and total index crimes as additional control variables along with race, region, poverty, age, and the sex ratio. The purpose of this extension is to ensure that any observed relationship between capital punishment and police killings is not simply an artifact of the levels of serious crime in a state.

Police Killing Rates. The dependent variable for this investigation is the rate of police killings per 1,000 FTE police employees. Rates are computed for each state for each year, 1973-1984.6 Police killing data were drawn from

6. Of note, in examining the bivariate correlates of police killings at the city and state levels of analysis, Lester (1978a, 1978b, 1982) chose to consider average rates of police homicides (1970-1975) due to the fluctuation in rates from year to year. In contrast, for the period under study here (1973-1984), annual rates of police killings for states are examined. 
the FBI's annual Uniform Crime Reports on Law Enforcement Officers Killed and Assaulted, and police employee figures were taken from annual issues of the Bureau of the Census's Public Employment bulletins.

Unfortunately, it is not possible to compute the rate of police homicides on the basis of FTE sworn police personnel for each year during the 12-year period. Since 1977, state-level figures on sworn personnel are available from the Census Bureau. For 1973 through 1976, however, only total FTE police employee data are available, which combine both civilian and sworn personnel. Therefore, to extend the analysis to the full time period, total police employee figures are used each year in computing police killing rates per 1,000 FTE personnel. The use of the more inclusive police employee figures has the effect of underreporting the actual rate of police killings. This is not a serious limitation, however. Rather, for the 8-year period where it is possible to compute killing rates on the basis of both total FTE police employees and total sworn FTE personnel, the two rates are correlated almost perfectly $(1977=.997,1978=.998,1979=.997,1980=.997,1981=.999,1982$ $=.983,1983=.996,1984=.999)$. The consistent and near-perfect association between the two rates clearly suggests that the use of police killing rates based upon total police employees is not a source of bias in this investigation.

Capital Punishment Measures. Three aspects of capital punishments are considered. First, abolitionist versus death penalty states are differentiated by a zero-one weighting, respectively. Death penalty status for each state is determined by the provision for capital punishment for murder as of the last day of the year. ${ }^{7}$ Second, the number of months per year that the death penalty was provided for by law in each state is considered. For this measure, states without capital punishment (abolitionist states) throughout the year receive a value of zero, while jurisdictions with the death penalty for some period during a year receive a value ranging from some fraction of a month to 12 for full-year retentionist states. ${ }^{8}$ This second operationalization of the

There is no indication that considering yearly police killing rates has biased the analysis. Rather, when the analysis to follow is replicated considering average rates for three periods (1973-1976, 1977-1979, 1980-1984), the pattern of findings for the death penalty variables remains the same.

7. While investigations of capital punishment and general homicides usually treat Vermont as an abolitionist state, here it is considered as a death penalty jurisdiction. In Vermont most forms of murder are not capital offenses, but since 1965 this state has retained the death penalty for the following offenses: murder of a police officer on duty or a prison guard, killings by a prisoner guilty of a prior murder, kidnapping for ransom, and the destruction of vital property by a group during wartime (Bowers, 1984).

8. The data for determining each state's death penalty status at the end of the year and the number of months each year where the death penalty was in effect for murder came from a recent inventory of legislative and judicial actions on capital punishment published by Bowers (1984), and the latest Capital Punishment. 1984 (1985) bulletin issued by the U.S. Department of Justice, Bureau of Justice Statistics. 
death penalty takes into account that during the period under study, there were considerable changes in some states in the provision for capital punishment due to (1) United States Supreme Court rulings such as Woodson and Lockett, (2) lower federal court and state supreme court actions, and (3) state legislative activity. The result of these actions, which only occasionally took effect at the beginning or end of calendar years, was that some "retentionist" states provided for capital punishment for only a portion of the year in which these changes occurred. For some states for some years, the death penalty was in effect for only a matter of weeks during a calendar year, whereas in other cases, capital punishment was available for much of the year, if not the entire year.

Third, the certainty of a death sentence for murder is considered. For each state for each year, the ratio of the number of prison admissions under a death sentence to the number of reported criminal homicides during the year is computed. Jurisdictions without capital punishment throughout the year have certainty values of zero, while retentionist states have certainty values that can range theoretically from zero to unity (1.0), depending upon the ratio of death sentences to homicides. For ease of interpretation, these certainty values are expressed as percentages rather than proportions or ratios. 9

To consider the typical time delay of at least one year between the commission of homicide and a possible death sentence (Ehrlich, 1975; Bailey, 1980b), a one-year lagged certainty index is formed by contrasting the number of death sentences each year (year $t$ ) with the number of criminal homicides the previous year (year $\mathrm{t}-1)$. This measure is also expressed in percentage terms. In addition, to consider the possibility that the deterrence relationship between capital sentences and police killings may be relatively long term, rather than confined within a one- or two-year period (year $t$ and year $t-1$ ), the relationship is examined between annual police killing rates (year $t$ ) and average certainty rates computed for cumulative periods ranging back five years (year $t$ through year $t-4$ ). Such cumulative periods have also been considered in capital punishment and general homicide studies.

As an alternative to the ratio measures, the number of death sentences imposed during each year (year $t$ ), the previous year (year $t-1$ ), and cumulative periods ranging back to year $t-4$ are considered as indicators of the certainty of capital punishment for murder. These measures take into account that would-be offenders may be more aware of, and influenced by, the sheer volume (number) of death sentences than the ratio of homicides to death sentences.

It is important to note that throughout the analysis, total homicides and

9. Figures for the number of persons sentenced to death and incarcerated each year were secured from the annual Capital Punishment series issued by the Bureau of Justice Statistics, U.S. Department of Justice. 
death sentences are considered in constructing certainty measures. Unfortunately, separate sentencing data for police killings are not available for all states and years included in the analysis. Importantly, too, a measure of certainty based upon actual executions is not considered. For the period under study (1973-1984), there were only 32 executions distributed among 11 states $($ Utah $=1$, Florida $=10$, Nevada $=1$, Indiana $=1$, Virginia $=2$, Texas $=$ 4 , Alabama $=1$, Mississippi $=1$, Louisiana $=6$, Georgia $=3$, North Carolina $=2$ ). Therefore, any certainty measure one might construct considering actual executions would have a value of zero for all but a few states for a few years. The restricted range of such an index precludes its use in the analysis.

Sociodemographic Control Variables. Selected sociodemographic factors (region of the country, percent black population, percent family poverty, the sex ratio, and population 15-34 years of age) are included in the regression equations as a means of statistical control. In choosing control variables, guidance was taken from findings of three analyses by Lester (1978a, 1978b, 1982) of the sociodemographic correlates of police killings and the suggestions of an anonymous reviewer of an earlier version of this paper.

Data for the control variables came from the Bureau of the Census, U.S. Department of Commerce, and the National Office of Vital Statistics. For most of these factors, adequate state-level data are not available for every year of the analysis. Figures for percent black population and family poverty are available in published census documents for 1970, 1975, and 1980. For both of these variables, linear interpolation is used to compute estimates for between years. For the 1981-1984 period, the race data are from unpublished figures provided by the Bureau of the Census; and, upon advice from the Department of Commerce, poverty figures for 1980 are used as the best available estimates for 1981 through 1984. Similarly, sex ratio figures are available only for the two decennial census years (1970 and 1980). Estimates for the interim years are computed by linear interpolation, and 1980 figures are used as the best available estimates for 1981-1984. For the age variable, official data are available for 1970 and 1980, as well as for 1981 through 1983. Thus, estimates of the proportion of the population age 15-34 for 1973-1979 were computed by linear interpolation, and 1983 figures are used as estimates for 1984 .

Finally, in considering region, states are differentiated as southern and nonsouthern using a dummy weighting of one and zero, respectively. Following the regional classification scheme of the Bureau of the Census, 16 states are considered as southern (Delaware, Maryland, Virginia, West Virginia, North Carolina, South Carolina, Georgia, Florida, Kentucky, Tennessee, Alabama, Mississippi, Arkansas, Louisiana, Oklahoma, Texas), and the remainder as nonsouthern.

Importantly, the sociodemographic factors are not incorporated into the analysis to present a formal theory/model of police killings. Rather, these 
factors are considered solely for control purposes to avoid possible spurious results for the death penalty variables.

\section{FINDINGS}

To reiterate, the model predicts a significant inverse relationship between police killing rates and (1) the provision for the death penalty - a zero/one dummy variable where death penalty status is determined as of the last day of each year, (2) the number of months during the year where the death penalty was in effect, and (3) the probability (percent or number) of criminal homicides resulting in a death sentence. The yearly zero-order correlations between police killing rates and the sanction and control variables are reported in Table 2. Space limitations preclude reporting a separate correlation matrix for each of the 12 years, 1973-1984.

For none of the 12 years does Table 2 reveal a significant negative bivariate association between police killing rates and the provision for capital punishment ${ }^{10}$ or the number of months the death penalty was a possible sanction during the year. Rather, in most cases the correlation between these factors is positive. In addition, the zero-order analysis fails to produce a single case of a significant inverse relationship between police killings and any of the lagged or nonlagged measures of the ratio or number of death sentences. Here, too, most of the coefficients are positive, slight in magnitude, and only in the chance range. Due to possible suppressor effects, however, these contrary bivariate results may not be trustworthy. Accordingly, these variables are considered in a simultaneous multivariate analysis.

Table 3 presents the analysis where annual police killing rates are regressed against the yearly sanction variables, including the ratio of homicides to death sentences during year $t$ and the control factors included in the basic model. For each variable unstandardized partial regression coefficients are reported.

As with the zero-order analysis, deterrence predictions are not borne out by Table 3 . Other things being equal, there is a tendency for death penalty states to have lower police killing rates for 6 of the 12 years, but where these two factors are negatively associated, the relationship is not statistically significant. In addition, for each year, the tradeoff between the provision for capital punishment and police killing rates is very slight in magnitude. For

10. Nor do average police killing rates for the two types of states provide general support for the deterrence hypothesis. Over the 12-year period, average police killings are higher for death penalty states in 9 cases $(1973=.36$ vs. $.20 ; 1974=.33$ vs. $.20 ; 1975=$ .28 vs. $.20 ; 1977=.22$ vs. $.15 ; 1979=.23$ vs. $.16 ; 1980=.19$ vs. $.05 ; 1981=.20$ vs. . 13 ; $1982=.16$ vs. $.15 ; 1984=.15$ vs. .13 ), and higher for abolitionist states for three years $(1976=.38$ vs. $.22 ; 1978=.20$ vs. $.19 ; 1983=.24$ vs. .13). Averaged over the dozen years, mean rates for death penalty $(\overline{\mathrm{X}}=.22)$ and abolitionist states $(\overline{\mathrm{X}}=.18)$ are also at odds with deterrence hypotheses. 
Table 2. Zero-Order Correlations Between Police Killing Rates, Sociodemographic Factors, Crime Rates, and Death Penalty Variablesa

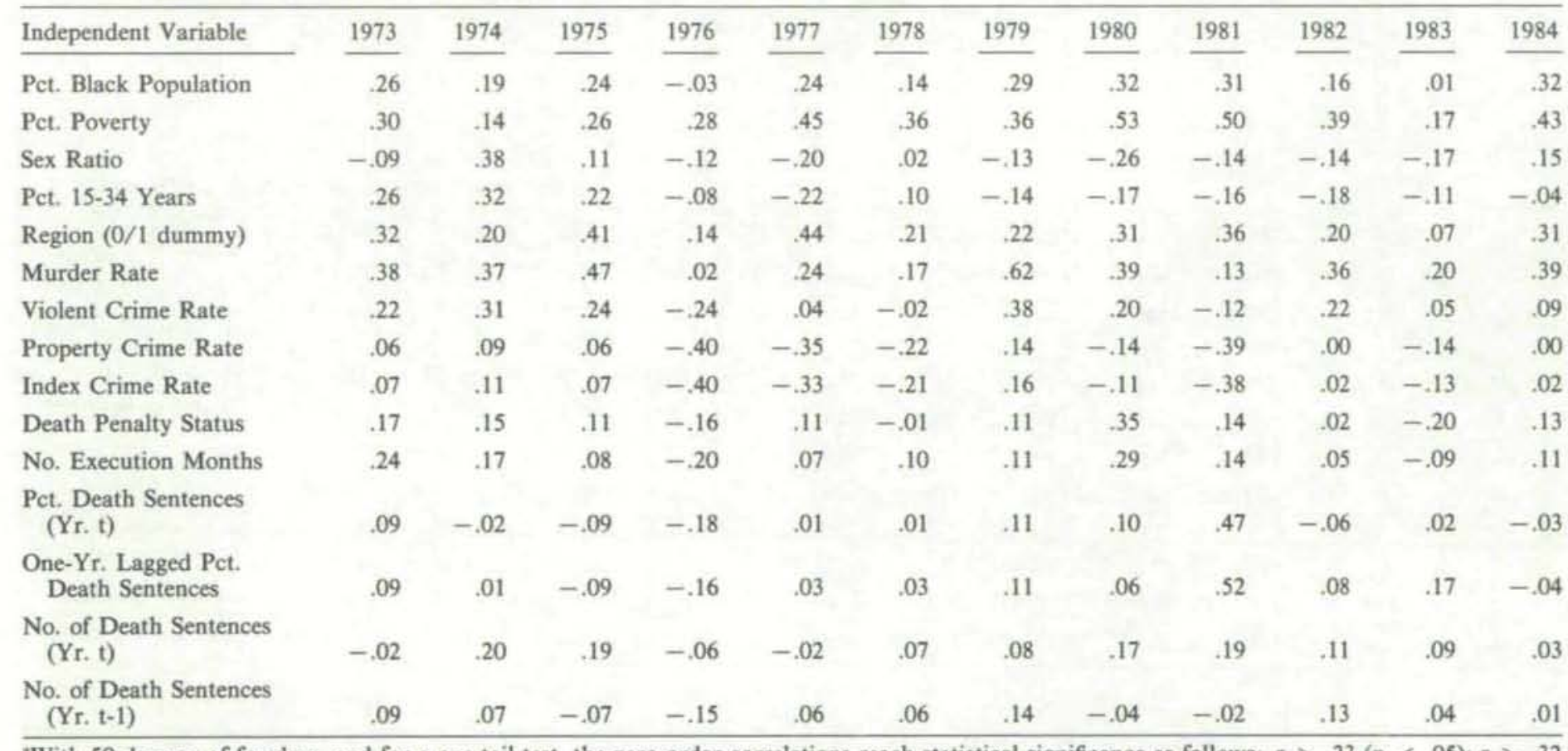

"With 50 degrees of freedom, and for a one-tail test, the zero-order correlations reach statistical significance as follows: $r\rangle .23$ (p $\langle .05$ ); $r\rangle .32$ $(\mathrm{p}<.01) ; \mathrm{r}>.35(\mathrm{p}<.005)$. 
Table 3. Regression Results Considering Police Killings and Three Death Penalty Variables Simultaneouslya

\begin{tabular}{|c|c|c|c|c|c|c|c|c|c|c|c|c|}
\hline Independent Variable & 1973 & 1974 & 1975 & 1976 & 1977 & 1978 & 1979 & 1980 & 1981 & 1982 & 1983 & 1984 \\
\hline Pct. Black Population & -.000 & $\overline{.011}$ & $\overline{-.003}$ & $-.024^{*}$ & -.007 & -.004 & $\overline{015^{*}}$ &.$- \overline{002}$ & $-\overline{.000}$ & $\overline{.001}$ & .002 & .008 \\
\hline Pct. Poverty & .003 & -.000 & .005 & .054 & $.031^{*}$ &, $036^{*}$ & .030 & $.037 * \bullet$ & $.035 * *$ & $.031^{*}$ & .023 & .024 \\
\hline Pct. 15-34 Years & .175 & -.030 & .058 & .057 & -.070 & .020 & -.009 & .003 & -.018 & -.002 & .016 & -.039 \\
\hline Region & .184 & .130 & $.373^{*}$ & .285 & $.249^{*}$ & .026 & -.047 & -.054 & .014 & -.005 & .010 & .022 \\
\hline Death Penalty Status & -.008 & .010 & -.133 & .075 & .076 & -.152 & .208 & .051 & -.116 & .028 & -.088 & -.170 \\
\hline $\begin{array}{l}\text { Death Sentence Certainty } \\
\text { (Yr. t) }\end{array}$ & -.099 & -.019 & -.027 & -.023 & -.041 & -.005 & .023 & -.012 & $.068^{\circ}$ & -.009 & .016 & -.013 \\
\hline Constant & 1.303 & $-5.463 * \cdots$ & -2.005 & 1.885 & .533 & -.448 & $-4.939 * \cdots *$ & .524 & .587 & -1.980 & $-3.433 * \ldots$ & $-1.895^{\circ}$ \\
\hline $\mathbf{R}^{2}$ & .288 & $.337^{*}$ & .273 & .242 & $.344^{*}$ & .189 & $.452 \cdots$ & $.358^{*}$ & $.385 * *$ & $.302^{*}$ & $.355^{\circ}$ & $.360^{*}$ \\
\hline
\end{tabular}

The figures reported are unstandardized partial regression coefficients.

$* \mathrm{p}<.05 \quad \cdots p<.01 \quad \cdots p<.001$ 
the combined 12-year period, the police killing rate per 1,000 FTE police personnel in states that provide for capital punishment is lower on average by only .018 than for abolitionist jurisdictions.

Similarly, Table 3 shows only a chance association between the number of months the death penalty was available and rates of police killings. For six years these two factors are negatively associated, and for the remaining years the association is positive. Regardless of direction, however, the relationship is extremely slight in magnitude. With the exception of $1973(\mathrm{~b}=.154)$, on balance over the 12-year period, a one-unit increase in death penalty months is associated with no more than .026 increase/decrease in the annual rate of police killings.

The evidence is no more supportive of the deterrence argument when the certainty of actual death sentences is considered. For 9 of the 12 years, states that made greater use of capital punishment in sentencing experienced lower rates of police killings. For each of these 9 years (1973-1978, 1980, 1982, $1984)$, however, this negative association is very slight $(\overline{\mathrm{X}}=-.03)$, and statistical significance is not achieved in a single case. Also, contrary to the deterrence argument, for three years $(1979,1981,1983)$ states that made greater use of capital sentencing experienced higher rates of police killings, and significantly so $(\mathrm{p}<.01)$ in 1981 .

It is not clear what significance should be attached to the isolated finding for the certainty variable for 1981. The "demand for punishment" and "brutalization" arguments (Bowers and Pierce, 1980) both posit a significant positive association between the level of homicides (in this case police killings) and capital punishment. However, if there is merit to either of these theses, the obvious question becomes why this "effect" $(\mathrm{b}=.068)$ is restricted to but a single year. ${ }^{11}$

The findings reported in Table 3 are clearly out of line with deterrence predictions and suggest that the provision for capital punishment and the level of use of the death sentence do not affect police killings. The question can be raised, however, whether the lack of support for the deterrence hypothesis is a consequence of the three death penalty variables being too collinear to be considered simultaneously in the regression equation. This question of redundancy was raised by an anonymous reviewer of an earlier version of this paper, and this issue is addressed in Table 4 where each death penalty variable is considered individually.

Table 4 provides no evidence that the earlier findings for the deterrence

11. While the issue of collinearity is discussed more generally below, it should be noted here that the atypical result for 1981 is not a consequence of multicollinearity among the three dimensions of capital punishment included in the model. The association between the certainty of a death sentence and both measures of the provision for capital punishment is only moderate $\left(R^{2}=.264\right)$. The same is true when the certainty index is regressed against all of the right-hand variables in the model $\left(\mathrm{R}^{2}=.427\right)$. 
Table 4. Regression Results Considering the Yearly Rate of Police Killings and Three Death Penalty Variables Individuallya

\begin{tabular}{|c|c|c|c|c|c|c|c|c|c|c|c|c|c|}
\hline Section & Independent Variable & 1973 & 1974 & 1975 & 1976 & 1977 & 1978 & 1979 & 1980 & 1981 & 1982 & 1983 & 1984 \\
\hline \multirow[t]{2}{*}{$\bar{A}$} & $\begin{array}{l}\text { Pet. Black Population } \\
\text { Pct. Poverty } \\
\text { Sex Ratio } \\
\text { Pct. 15-34 Years } \\
\text { Region } \\
\text { Death Penalty Status }\end{array}$ & $\begin{array}{c}-.001 \\
.009 \\
-.057^{*} \\
.170^{* *} \\
.163 \\
.028\end{array}$ & $\begin{array}{l}.010 \\
.000 \\
.066 * * \\
-.039 \\
.150 \\
.169\end{array}$ & $\begin{array}{r}-.003 \\
.003 \\
.011 \\
.028 \\
.364^{\bullet} \\
-.009\end{array}$ & $\begin{array}{r}-.020 \\
.061^{*} \\
-.025 \\
.021 \\
.164 \\
-.202\end{array}$ & $\begin{array}{r}-.007 \\
.030 \\
.011 \\
-.065 \\
.245^{\circ} \\
-.003\end{array}$ & $\begin{array}{r}-.004 \\
.036 * \\
-.004 \\
.034 \\
.035 \\
-.031\end{array}$ & $\begin{array}{l}\overline{.014^{*}} \\
.035^{*} \\
.046^{* *} \\
-.002 \\
-.106 \\
.036\end{array}$ & $\begin{array}{c}-.002 \\
.037 * \bullet \\
-.009 \\
.007 \\
-.051 \\
.085\end{array}$ & $\begin{array}{r}.001 \\
.039 * \\
.010 \\
-.044 \\
.047 \\
-.051\end{array}$ & $\begin{array}{l}\overline{.001} \\
.031 \bullet \\
.015 \\
.005 \\
-.016 \\
-.022\end{array}$ & $\begin{array}{l}.003 \\
.022 \\
.032 \bullet \\
.011 \\
.012 \\
-.083\end{array}$ & $\begin{array}{l}.007 \\
.025 \\
.026 * \bullet \\
-.026 \\
.005 \\
-.003\end{array}$ \\
\hline & $\begin{array}{l}\text { Constant } \\
\mathrm{R}^{2}\end{array}$ & $\begin{array}{l}1.120 \\
.274^{*}\end{array}$ & $\begin{array}{c}-5.274 * * * \\
.309 * *\end{array}$ & $\begin{array}{r}-1.689 \\
.226\end{array}$ & $\begin{array}{r}1.839 \\
.196\end{array}$ & $\begin{array}{l}.584 \\
.322^{\circ}\end{array}$ & $\begin{array}{r}-.622 \\
.161\end{array}$ & $\begin{array}{r}-4.557 * \cdots \\
.423 * \cdots\end{array}$ & $\begin{array}{l}.412 \\
.349 * *\end{array}$ & $\begin{array}{l}.417 \\
.304^{*}\end{array}$ & $\begin{array}{r}-1.734^{*} \\
.276^{*}\end{array}$ & $\begin{array}{c}-3.442 * \cdots \\
.351 \cdots *\end{array}$ & $\begin{array}{r}-1.679^{*} \\
.319 * \bullet\end{array}$ \\
\hline \multirow[t]{2}{*}{ B } & $\begin{array}{l}\text { Pct. Black Population } \\
\text { Pct. Poverty } \\
\text { Sex Ratio } \\
\text { Pet. 15-34 Years } \\
\text { Region } \\
\text { No. Death Penalty Months }\end{array}$ & $\begin{array}{c}-.000 \\
.007 \\
-.055^{*} \\
.164^{* *} \\
.165 \\
.009\end{array}$ & $\begin{array}{c}.013 \\
-.002 \\
.069 * * \\
-.052 \\
.130 \\
.017\end{array}$ & $\begin{array}{l}-.003 \\
.003 \\
.011 \\
.027 \\
.363 \\
.000\end{array}$ & $\begin{array}{r}-.022 \\
.060^{*} \\
-.030 \\
.041 \\
.217 \\
-.025\end{array}$ & $\begin{array}{r}-.007 \\
.030 \\
.010 \\
-.064 \\
.250^{*} \\
-.003\end{array}$ & $\begin{array}{r}-.005 \\
.037 \\
-.003 \\
.034 \\
.014 \\
.003\end{array}$ & $\begin{array}{l}.015^{*} \\
.036^{*} \\
.045^{*} * \\
-.002 \\
-.089 \\
-.003\end{array}$ & $\begin{array}{c}.000 \\
.038 * . \\
-.009 \\
.001 \\
-.073 \\
.007\end{array}$ & $\begin{array}{r}.000 \\
.039 * \\
.010 \\
-.042 \\
.052 \\
-.002\end{array}$ & $\begin{array}{l}.001 \\
.031^{*} \\
.016 \\
.005 \\
-.007 \\
-.003\end{array}$ & $\begin{array}{c}.003 \\
.021 \\
.034^{* .} \\
.001 \\
.027 \\
-.006\end{array}$ & $\begin{array}{l}.007 \\
.025 \\
.025 * * \\
-.025 \\
.004 \\
.001\end{array}$ \\
\hline & $\begin{array}{l}\text { Constant } \\
\mathbf{R}^{2}\end{array}$ & $\begin{array}{l}1.107 \\
.276^{*}\end{array}$ & $\begin{array}{c}-5.263 * * * \\
.318 * *\end{array}$ & $\begin{array}{r}-1.717 \\
.226\end{array}$ & $\begin{array}{r}1.860 \\
.224\end{array}$ & $\begin{array}{l}.626 \\
.325 * *\end{array}$ & $\begin{array}{r}-.719 \\
.162\end{array}$ & $\begin{array}{r}-4.511 * * * \\
.423 * * *\end{array}$ & $\begin{array}{l}.589 \\
.351 *\end{array}$ & $\begin{array}{l}.325 \\
.300^{*}\end{array}$ & $\begin{array}{r}-1.802^{* *} \\
.280^{*}\end{array}$ & $\begin{array}{c}-3.632 * * * \\
.348 * *\end{array}$ & $\begin{array}{r}-1.699^{*} \\
.320^{*} *\end{array}$ \\
\hline \multirow[t]{2}{*}{ C } & $\begin{array}{l}\text { Pct. Black Population } \\
\text { Pct. Poverty } \\
\text { Sex Ratio } \\
\text { Pct. 15-34 Years } \\
\text { Region } \\
\text { Death Sentence Certainty }\end{array}$ & $\begin{array}{c}-.002 \\
.006 \\
-.063^{*} \\
.185^{* *} \\
.180\end{array}$ & $\begin{array}{c}.012 \\
.002 \\
.056^{*} \\
-.013 \\
.124\end{array}$ & $\begin{array}{r}-.005 \\
.007 \\
.004 \\
.051 \\
.418^{*}\end{array}$ & $\begin{array}{r}-.025 * \\
.053 \\
-.026 \\
.033 \\
.249\end{array}$ & $\begin{array}{c}-.007 \\
.031^{*} \\
.011 \\
-.066 \\
.251^{*}\end{array}$ & $\begin{array}{r}-.005 \\
.037 \\
-.004 \\
.035 \\
.029\end{array}$ & $\begin{array}{c}.015^{*} \\
.036^{*} \\
.044^{* *} \\
.002 \\
-.108\end{array}$ & $\begin{array}{c}-.000 \\
.039 * \\
-.008 \\
.002 \\
-.053\end{array}$ & $\begin{array}{c}-.002 \\
.034^{*} \\
.001 \\
-.021 \\
.013\end{array}$ & $\begin{array}{l}.001 \\
.031 \cdots \\
.020 \\
-.003 \\
-.014 \\
-.010\end{array}$ & $\begin{array}{l}.002 \\
.021 \\
.033 * . \\
.011 \\
.013\end{array}$ & $\begin{array}{c}.008 \\
.024 \\
.028 * \bullet \\
-.034 \\
.011\end{array}$ \\
\hline & $\begin{array}{l}(\mathrm{Yr}, \mathrm{t}) \\
\text { Constant } \\
\mathrm{R}^{2}\end{array}$ & $\begin{array}{c}-.064 \\
1.354 \\
.279 *\end{array}$ & $\begin{array}{c}-.009 \\
-4.908 * \cdots \\
.280^{\circ}\end{array}$ & $\begin{array}{r}-.036 \\
-1.605 \\
.287^{\bullet}\end{array}$ & $\begin{array}{r}-.032 \\
1.569 \\
.196\end{array}$ & $\begin{array}{c}-.040 \\
.582 \\
.339 * *\end{array}$ & $\begin{array}{r}-.002 \\
-.688 \\
.158\end{array}$ & $\begin{array}{r}.011 \\
-4.465 * \cdots \\
.422 * \cdots\end{array}$ & $\begin{array}{l}.007 \\
.526 \\
.315 * 0\end{array}$ & $\begin{array}{l}.050 \\
.445 \\
.350^{* \bullet}\end{array}$ & $\begin{array}{r}-.010 \\
-1.910^{*} \\
.300^{*}\end{array}$ & $\begin{array}{c}-.000 \\
-3.659 * \cdots \\
.333 * *\end{array}$ & $\begin{array}{r}-.011 \\
-1.676^{*} \\
.342^{* *}\end{array}$ \\
\hline
\end{tabular}

The figures reported are unstandardized partial regression coefficients.

$* \mathrm{p}<.05 \quad \cdots p<.01 \quad \cdots p<.001$ 
variables are an artifact of problems of collinearity. To the contrary, the results mirror almost perfectly the earlier analysis. Section A of Table 4 shows only chance associations between states' death penalty status and police killing rates, and Section B shows no consistent positive or negative association between rates and the portion of the year that the death penalty is prescribed. Similarly, Section C of Table 3 shows that in the majority of cases (9 of 12 years), higher probabilities of receiving a death sentence are associated with lower police killing rates, but these negative relationships are very slight and do not depart from a chance level.

This same pattern holds when the analysis reported in Section C of Table 4 is replicated examining yearly police killing rates (year t) and (1) a one-year lagged certainty index contrasting homicides in year $t-1$ and death sentences in year $t,(2)$ certainty ratios considering death sentences for cumulative periods up to five years, (3) the number of annual death sentences as an alternative operationalization of certainty, and (4) the number of cumulative death sentences spanning periods up to five years. Space limitations preclude reporting the results of these extended analyses in tabular form. (They are available upon request.)

\section{POLICE KILLINGS AND OTHER CRIMES}

To this point the research has revealed no consistent evidence that capital punishment provides an effective deterrent to police killings. It is possible, however, that at least in part these findings are a result of how the model has been specified. Race, region, poverty, age and the sex ratio have been considered as control variables. Not considered in the model, however, is the crime rate, which may be tied to the level of police killings (Lester, 1978b).

A recent FBI (1985) report on Police Officers Killed and Assaulted in 1984 reveals that a very sizable proportion of slain officers lose their lives doing normal police work such as investigating "man with a gun" calls, responding to robberies in progress, pursuing burglary and robbery suspects, and attempting other arrests. In contrast, very few officers are killed in nonroutine situations such as dealing with civil disorders, from entrapment and unprovoked ambushes, and from attacks by "mentally deranged" persons. The same pattern holds for the other years under consideration here.

Since most police killings are an outgrowth of responding to reported or suspected crimes, it might be argued that the rate of police homicides is largely a product of the level of serious crime in a community. That is, the greater the number of serious crimes, the greater the possible violent policesuspect confrontations, and the greater the possible lethal consequences for police. If police killings are largely a by-product of doing police work, then one would expect a significant positive relationship between the rate of police homicides and the rate of serious crimes. More importantly for the present purposes, ignoring such a possibility in specifying the model could have 
biased the findings in the direction of masking an actual deterrent effect for the death penalty variables.

To explore this question, the type of analysis reported in Table 3 is replicated, but with the addition of felony rates for violent crimes (murder, assault, forcible rape, robbery), property crimes (burglary, grand larceny, auto theft) and total index crimes. Due to space constraints, Table 5 reports a summary of the important test statistics for the three death penalty variables only. The coefficients in Section A represent the basic model extended to include rates of violent crime; Section B of property crime; and Section C of total index crimes.

Extending the model to include rates for major crimes does not alter the pattern of findings for the death penalty variables. For Section A of Table 5 where the rate of violent crimes is considered as a control factor, none of the capital punishment variables are associated negatively and significantly with police killings. For Section B where property crimes are considered, the same is true. And when the rate of total index crimes is held constant (Section C of Table 5), there is also no indication that the provision for capital punishment, and its use in sentencing, influences police killings. Indeed, the pattern of findings presented in Table 5 parallels almost perfectly the results of the earlier analyses (Tables 3 and 4) which do not consider felony rates.

Of note, although not shown in Table 5, police killing rates are not associated significantly $(\mathrm{p}<.05)$ with crime rates for violent offenses, property offenses, or total index offenses for a single year. In addition, comparison of the $\mathrm{R}^{2}$ values in Table 5 with their counterparts in the earlier analyses (Tables 3 and 4 ) shows that the addition of different types of crime rates to the model adds nothing of significance to a better understanding of police killings. Rather, the overall goodness of fit of the basic (Table 3 ) and the extended models (Table 5) is essentially the same. Accordingly, these results do not support the conclusion that police killings are largely a consequence of the level of the crime problem and doing police work.

\section{RESULTS FOR REDUCED MODELS}

To this point, the multivariate analysis provides no evidence that state police killing rates for the 1973-1984 period were tied to the statutory provision for capital punishment, the period of the year where the death penalty was in effect in retentionist states, and the various dimensions of the certainty of a death sentence examined. However, in a cross-sectional analysis of only 50 states, and considering a number of predictor variables, degrees of freedom become constrained and statistically significant results are more difficult to achieve. Of note, for the basic model (Table 3), degrees of freedom are restricted to 8 and 41 , and when the analysis is extended to include crime rates as additional predictors (Table 5), degrees of freedom are reduced to 9 and 40. 
Table 5. Summary of Regression Results for Death Penalty Variables Where the Rate of Violent Crimes, Property Crimes, and Total Index Crimes are Included in the Modela

\begin{tabular}{|c|c|c|c|c|c|c|c|c|c|c|c|c|c|}
\hline Section & Independent Variable & 1973 & 1974 & 1975 & 1976 & 1977 & 1978 & 1979 & 1980 & 1981 & 1982 & 1983 & 1984 \\
\hline \multirow{2}{*}{ A } & No. Execution Months & .015 & .018 & .008 &,- 023 & -.005 & .012 & -.017 & .003 & .000 & -.000 & -.001 & .023 \\
\hline & $\mathbf{R}^{2}$ & .287 & $.344^{*}$ & .298 & .274 & $.342^{\circ}$ & 191 & $.500^{* \cdots *}$ & $.376^{*}$ & $.468 * \cdots$ & $.332^{*}$ & $.351^{*}$ & $.367^{\circ}$ \\
\hline \multirow{2}{*}{ B } & $\begin{array}{c}\text { Death Sentence Certainty } \\
\left(\mathrm{Y}_{\mathrm{r}, \mathrm{t}}+\mathrm{Y}_{\mathrm{r}, \mathrm{t}}-1\right) / 2\end{array}$ & -.081 & -.019 & -.036 & -.017 & -.029 & .001 & .006 & -.020 & $.085^{* \bullet}$ & -.013 & -.006 & -.013 \\
\hline & $\mathbf{R}^{2}$ & .292 & $.335^{*}$ & .306 & .289 & $.346^{*}$ & .193 & $.476 * \cdots$ & $.372^{*}$ & $.470^{* * * *}$ & .309 & $.372^{\bullet}$ & $.359^{*}$ \\
\hline C & Death Penaity Status & -.027 & .020 & -.020 & .113 & .104 & -.134 & .146 & .047 & -.106 & -.014 & -.049 & -.170 \\
\hline
\end{tabular}

"Figures reported are unstandardized partial regression coefficients.

"Results in Section A are when percent black population, percent poverty, region, percent 15-34 years of age, the sex ratio, and rates of violent crime are used as control variables. Resuits in Section B are when the five sociodemographic variables and rates of property crime are controlled. Results in Section $\mathrm{C}$ are when the sociodemographic variables and total index crime rates are controlled.

*p $<.05 \quad * p<.01 \quad * * p<.001$ 
Although the equally negative results for the death penalty variables found at the bivariate level (Table 1) suggest that the multivariate analysis is not biased seriously due to constraints in degrees of freedom, this issue is explored further by replicating the earlier analysis (Tables 3 ) excluding all control variables that do not achieve statistical significance at the .05 level, but including all three dimensions of the death penalty (none of which achieve statistical significance in the hypothesized direction). Following this course, the reduced form models include the capital punishment variables and the specified control variable(s) for the respective years: (1) percent poverty for 1978 and 1980-1982, (2) the sex ratio for 1974, 1983, and 1984, (3) percent black population for 1976, (4) percent black population and the sex ratio for 1979, and (5) region and poverty for 1977. For 1973, none of the control variables are associated significantly with police killing rates.

In this reduced form analysis, the maximum number of predictors considered does not exceed five (and in some cases there are only three). With a minimum ratio of 10 observations per variable included in the reduced models, degrees of freedom problems can be safely ruled out as responsible for the nonsignificant results for the death penalty variables. Results of this analysis are reported in Table 6.

There is no indication in this table that the previously reported nonsignificant findings for the death penalty variables result from bias due to the ratio of observations to constants in the regression models. To the contrary, excluding nonsignificant control variables from the analysis continues to produce only chance associations between police killing rates and provision for the death penalty, the period it was in effect during each year, and a certainty index based upon the ratio of death sentences to homicides during the year (year $\mathrm{t}$ ).

In addition, when the same reduced form analysis is replicated substituting each alternative nonlagged, lagged, and cumulative indicator of the certainty of a death sentence (discussed above), the same nonsignificant pattern is found. Moreover, when the reduced form model of police killings is modified to exclude all of the control factors for each year (and thereby only includes the three death penalty variables), neither the provision for capital punishment nor its level of use in sentencing is a significant predictor of police killing rates. In short, there is simply no evidence of deterrence in these or the previously examined data. 12

12. As a further check on how limited degrees of freedom may have biased the statistical significance of the results for the capital punishment variables, an anonymous reviewer of an earlier version of the paper has suggested that a pooled cross-sectional and time-series analysis be conducted of the 50 states and 12 years, thus yielding 600 observations. This suggestion has been followed with the basic model (Table 3 ), and with each variation considering alternative certainty measures and crime rates variables (as in Table 5). This analysis shows a statistically significant positive relationship between police killing rates and 
Table 6. Regression Results for Reduced Models of Police Killingsa

\begin{tabular}{|c|c|c|c|c|c|c|c|c|c|c|c|c|}
\hline Independent Variable & 1973 & 1974 & 1975 & 1976 & 1977 & 1978 & 1979 & 1980 & 1981 & 1982 & 1983 & 1984 \\
\hline Pct. Poverty & - & - & - & - & .027 & $.032^{\bullet \bullet}$ & - & $.031 \bullet \cdots$ & $.037^{*}$ & $.028^{\circ \bullet}$ & - & - \\
\hline Region & - & - & .344 & - & .155 & - & - & - & - & - & - & 一 \\
\hline Death Penalty Status & .088 & .118 & -.061 & .017 & .009 & -.190 & .254 & .077 & -.080 & -.102 & -.036 & .031 \\
\hline Constant & .174 & $-4.177^{* *}$ & .164 & $.409 * *$ & -.084 & -.092 & $-4.819 * * *$ & $-.206^{*}$ & -.168 & -.069 & $-2.599 * *$ & -.951 \\
\hline $\mathbf{R}^{2}$ & .062 & $.223^{*}$ & $.207^{*}$ & .050 & $.257^{\circ}$ & .174 & $.406 * * *$ & $.329 * \bullet *$ & $.422 * \cdots$ & .174 & $.240^{*}$ & .065 \\
\hline
\end{tabular}

The figures reported are unstandardized partial regression coefficients.

$* \mathrm{p}<.05 \quad * \mathrm{p}<.001 \quad * * \mathrm{p}<.001$ 


\section{SUMMARY AND CONCLUSION}

In American society, law enforcement is a hazardous and often deadly business. Indeed, the rate of lethal assaults against police is higher than for any other profession (Lester, 1982), and well exceeds the homicide rate of citizens (see Table 1). Despite the high rate of police homicides, with few exceptions, the etiology of police killings has been all but ignored in recent criminological literature. Drawing upon deterrence theory, this paper is intended to shed additional light on this issue by examining whether police are afforded an added measure of protection against death by the provision for and use of capital punishment (that is, capital sentencing). Since the Furman decision of 1972, there has been a growing and dramatic reaffirmation of capital punishment in the country, and a concomitant decline in police killings. The possible link between these two trends has been explored in this paper.

Like previous studies (Sellin, 1967, 1980; Cardarelli, 1968; Bailey, 1982), the present analysis lends no support to the view that the death penalty provides a more effective deterrent to police homicides than alternative sanctions. Not for a single year was evidence found that police are safer in jurisdictions that provide for capital punishment. Nor did the analysis produce a single instance where higher levels of death sentences are associated significantly with lower rates of police killings. These findings coupled with Bailey's (1982) suggest, then, that the role of capital punishment in police homicides does not depend upon the degree of public and political activity centering on capital punishment, even if such activity affirms the legitimacy of this type of sanction.

In sum, the safety of police officers from lethal violence is an important problem, but its resolution does not lie in capital punishment. Rather, police homicides may be highly situational in nature. If so, Creamer and Robin (1970: 494) may have been correct when they argued that "paramount in solving the assault of police problem is the great need for special training of police officers ... to anticipate and handle potential assaults." The present authors disagree with Creamer and Robin (1970: 494), however, that "only the police can effectively take measures to prevent assaults" (emphasis added).

In better realizing the goal of police safety, social scientists can also make a contribution. The key behind the special training required to better anticipate and handle police assaults is a better understanding of the causes and characteristics of such assaults. While it seems doubtful that macroscopic,

percent poverty, the sex ratio and region of the country. In addition, there is a significant downward linear trend in rates over the 12 years. But again, contrary to the deterrence hypothesis, there are only chance associations between police killings and the provision for capital punishment and its level of use in sentencing. This pattern holds regardless of how the certainty variable is operationalized. 
social structural analyses will be of much help, ${ }^{13}$ situational and social psychological examinations of the dynamics of police-citizen assaults, lethal and otherwise, may hold promise. Such investigations may provide an important added ingredient in police training which may (along with improved technology) substantially reduce police killings. Of course, the payoff of such research remains to be seen. However, from this and previous investigations, it appears futile to maintain hope that the lives and safety of police officers can be preserved by capital punishment.

13. This judgment is based on the weak, and in most cases nonsignificant, relationship between police killing rates and the sociodemographic factors and crime rate variables considered in this analysis.

\section{REFERENCES}

Bailey, William C.

1977 Imprisonment vs. the death penalty as a deterrent to murder. Law and Human Behavior 1: 239-260.

1980a A multivariate cross-sectional analysis of the deterrent effect of the death penalty. Sociology and Social Research 64: 183-207.

1980b Deterrence and the celerity of the death penalty: A neglected question in deterrence research. Social Forces 58: 1,308-1,333.

1982 Capital punishment and lethal assaults against police. Criminology 19: 608. 625.

1984a Disaggregation in deterrence and death penalty research: The case of murder in Chicago. Journal of Criminal Law and Criminology 74: 827-859.

1984b Murder and capital punishment in the nation's capital. Justice Quarterly 1: 211-233.

Black, Theodore and Thomas Orsagh

1978 New evidence on the efficacy of sanctions as a deterrent to homicide. Social Science Quarterly 58: 616-631.

Bowers, William J.

1984 Legal Homicide: Death as Punishment in America, 1964-1982. Boston: Northeastern University Press.

Bowers, William and Glen Pierce

1975 The illusion of deterrence in Isaac Ehrlich's research on capital punishment Yale Law Journal 85: 187-208.

1980 Deterrence or brutalization: What is the effect of executions? Crime and Delinquency 26: 453-484.

Cardarelli, Albert P.

1968 An analysis of police killed in criminal action: 1961-1963. Journal of Criminal Law, Criminology and Police Science 59: 447-453.

Coker v. Georgia. 433 U.S. 584, 97 Sup. Ct. 2861 (1977).

Creamer, J. Shane and Gerald D. Robin

1970 Assaults on police. In Samuel G. Chapman (ed.), Police Patrol Readings (2nd ed.). Springfield, IL: Thomas. 
Dann, Robert

1935 The Deterrent Effect of Capital Punishment. Philadelphia: The Committee of Philanthropic Labor of Philadelphia Yearly Meeting of Friends.

Ehrlich, Isaac

1975 The deterrent effect of capital punishment: A question of life or death. The American Economic Review 65: 397-417.

1977 Capital punishment and deterrence: Some further thoughts and additional evidence. Journal of Political Economy 85: 741-788.

Federal Bureau of Investigation

1985a Crime in the United States: Uniform Crime Reports-1984. Washington, D.C.: Government Printing Office.

1985b Uniform Crime Reports: Law Enforcement Officers Killed and Assaulted1984. Washington, D.C.: U.S. Department of Justice.

Forst, Brian

1977 The Deterrent Effect of Capital Punishment: A Cross-State Analysis of the 1960s. Minnesota Law Review 61: 743-767.

1983 Capital punishment and deterrence: Conflicting evidence? Journal of Criminal Law and Criminology 74: 927-942.

Furman v. Georgia, 408 U.S. 238 (1972).

Gibbs, Jack

1975 Crime, Punishment and Deterrence. New York: Elsevier.

Gregg v. Georgia. 96 Sup. Ct. 2902 (1976).

Jurek v. Texas. 428 U.S. 262 (1976).

Lehtinen, Marlene

1977 The value of life: An argument for the death penalty. Crime and Delinquency 23: 237-252.

Lester, David

1978a A study of civilian caused murders of police officers. International Journal of Criminology and Penology 6: 373-378.

1978b Predicting murder rates of police officers in urban areas. Police Law Quarterly 7: 20-25.

1982 Civilians who kill police officers and police officers who kill civilians: A comparison of American cities. Journal of Police Science and Administration 10: 384-387.

Lockett v. Ohio. 438 U.S. 586 (1978).

McFarland, Sam G.

1983 Is capital punishment a short-term deterrent to homicide? A study of the effects of four recent American executions. Journal of Criminal Law and Criminology $74:$ 1,014-1,030.

Nicolai, Sandra, Karen Riley, Rhonda Christansen, Patricia Styon, and Leslie Creunke 1980 The Question of Capital Punishment. Lincoln, NE: Contact.

Passell, Peter

1975 The deterrent effect of the death penalty: A statistical test. Stanford Law Review 28: 61-80. 
Passell, Peter and John Taylor

1975 The deterrent effect of capital punishment: Another view. Discussion Paper 74-7509. New York: Columbia University.

Phillips, David

1980 The deterrent effect of capital punishment: New evidence on an old controversy. American Journal of Sociology 86: 139-148.

Proffitt v. Florida. 428 United States 242 (1976).

Roberts (Harry) v. Louisiana. 431 United States 633 (1977).

Roberts (Stanislaus) v. Louisiana. 96 Supreme Court 3001 (1976).

Savitz, Leonard

1958 A study of capital punishment. Journal of Criminal Law, Criminology and Police Science 49: 338-341.

Sellin, Thorsten

1967 Capital Punishment: New York: Harper and Row.

1980 The Penalty of Death. Beverly Hills: Sage.

Tittle, Charles

1980 Sanctions and Social Deviance: The Question of Deterrence. New York: Praeger.

United States Department of Justice, Bureau of Justice Statistics

1985 Capital Punishment 1984. Washington, D.C.: U.S. Government Printing Office.

van den Haag, Ernest

1969 On deterrence and the death penalty. Journal of Criminal Law, Criminology and Police Science 60: 141-147.

van den Haag, Ernest and John Conrad

1983 The Death Penalty: A Debate. New York: Plenum.

Woodson v. North Carolina. 96 Supreme Court. 2978 (1976).

Yunker, James

1976 Is the death penalty a deterrent to homicide? Some time series evidence. Journal of Behavioral Economics 5: 1-32.

1982a Testing the deterrent effect of capital punishment: A reduced form approach. Criminology 19: 626-649.

1982b The relevance of the identification problem to statistical research on capital punishment. Crime and Delinquency 28: 96-124.

William C. Bailey is Professor of Sociology and Associate Dean of the Graduate School, Cleveland State University. His major research interests include crime and deterrence, capital punishment, and urban crime patterns.

Ruth D. Peterson is Assistant Professor of Sociology, Ohio State University. Her major research interests include legal decision making and sentencing, crime and deterrence.

Post-print standardized by MSL Academic Endeavors, the imprint of the Michael Schwartz Library at Cleveland State University, 2014 